\title{
Effect of Administration of Actinomycin D and Protein-Synthesis Inhibitors on the Binding of Prolactin to the Mammary Gland Prolactin Receptor in the Ovariectomized Mid-Pregnant Mouse
}

Senkiti SAKAI

Department of Animal Breeding, Faculty of Agriculture, University of Tokyo, Bunkyo-ku, Tokyo 113

(Received May 27, 1991)

\begin{abstract}
In ovariectomized mid-pregnant mice, specific prolactin (PRL) binding to the mammary receptor began to increase around $16 \mathrm{~h}$ of ovariectomy. The effects of an inhibitor of transcription (actinomycin D) and of translation (cycloheximide) on the increase in PRL binding were examined in vivo. Actinomycin $\mathrm{D}$ which was administered between 0 and $12 \mathrm{~h}$ after ovariectomy inhibited the increase in PRL binding, while cycloheximide inhibited the increase by the injection after $16 \mathrm{~h}$ of ovariectomy. The mammary gland, collected at 24 or $36 \mathrm{~h}$ of ovariectomy, was incubated in the presence of actinomycin $\mathrm{D}$, cycloheximide or puromycin in vitro. Although actinomycin $\mathrm{D}$ showed little or no effect on the amount of PRL binding, inhibitors of translation suppressed the binding significantly as compared with in the absence. It was concluded that the increase in PRL binding caused by ovariectomy was mediated by the initiation of the receptor synthesis. It was suggested that transcription for the receptor synthesis occurred shortly after ovariectomy.
\end{abstract}

Anim. Sci. Technol. (Jpn.) 63 (1): 1-7, 1992

Key words : Mammary gland, Ovariectomy, Prolactin, Receptor, Receptor synthesis

As pregnancy is sustained by high levels of serum progesterone, the progesterone withdrawal acts as the trigger of abortion. It has been shown that ovariectomy induces an increase in mammary prolactin (PRL) receptor and initiates lactose synthesis in the mouse ${ }^{1)}$ and $\mathrm{rat}^{2)}$. The concentration of placental lactogen is very high from mid- to late pregnancy and disappears rapidly from circulation after parturition ${ }^{6,12,13)}$. It has been interpreted that the apparent low capacity of PRL binding during pregnancy is caused by a masking effect of a large amount of placental lactogen ${ }^{5}$. With the evidence that simultaneous removal of adrenal glands inhibits the ovariectomyinduced increase in the PRL receptors ${ }^{2,3)}$, it is also probable that the progesterone withdrawal initiates synthesis of the PRL receptor.

In this study, an inhibitor of transcription or translation was injected at different time after ovariectomy and the effect of the inhibitor on the PRL binding to mammary gland was examined. The serum concentration of lactogenic activity was also determined by a radioreceptor assay.

\section{Materials and Methods}

Hormones and chemicals : Ovine PRL (NIH-P- 
S 15) was supplied by NIADDK, Bethesda, Md., USA. Actinomycin D, cycloheximide, and puromycin were from Wako Chemicals, Osaka. Bovine serum albumin (BSA) was from Seikagaku Kogyo, Tokyo. Medium 199 was from Difco Laboratories, Detroit, Mich., USA.

PRL binding- and radioreceptor assays: PRL was iodinated by the lactoperoxidase and hydrogen peroxide method ${ }^{10)}$. The specific radioactivity of ${ }^{125}$ I-PRL used was about 2.6 $\mathrm{MBq} / \mu \mathrm{g}$.

The procedure of PRL binding assay has previously been described ${ }^{12)}$. The third thoracic mammary gland was cut into $0.5-\mathrm{mm}$ thick slices by a tissue slicer (Hotta Rika, Tokyo). Three slices $(10-15 \mathrm{mg})$ were incubated at $37^{\circ} \mathrm{C}$ for $2 \mathrm{~h}$ in $1 \mathrm{ml}$ Medium 199-0.2\% BSA (pH 7.4) containing ${ }^{125} \mathrm{I}-\mathrm{PRL}(80,000-100,000 \mathrm{cpm})$ in the presence or absence of $5 \mu \mathrm{g}$ of unlabeled PRL. At the end of the incubation, the slices were washed with physiological saline and weighed. Radioactivity in the slices was determined in a gamma counter. The experiments were performed in duplicate.

The serum lactogenic activity was determined by a radioreceptor assay using the midlactating mammary gland and ovine $\mathrm{PRL}^{9 \text { ) }}$. Fifty $\mu l$ of the serum or unlabeled PRL solutions were included in the reaction mixture. The dose displacement curve was constructed using unlabeled PRL $(0,2.5-80 \mathrm{ng}, 5 \mu \mathrm{g})$ and the serum concentration of lactogenic activity was expressed as the concentration of standard ovine PRL.

In vivo and in vitro experiments: Inbred dd strain mice bred in our laboratory were used. The day on which a vaginal plug was found was taken as day 0 of pregnancy. Ovariectomy or sham-ovariectomy was performed under pentobarbitone sodium anaesthesia at $09.00-$ 10.30 on day 13 of pregnancy. Animals were killed by cervical dislocation. Blood samples were collected by heart puncture without anaesthesia and the serum concentration of lactogenic hormone was measured by a radio- receptor assay ${ }^{3)}$.

A single dose of actinomycin D $(10 \mu \mathrm{g} / \mathrm{head})$ or cycloheximide $(1 \mathrm{mg})$ dissolved in physiological saline was subcutaneously injected every $4 \mathrm{~h}$ from 0 to $24 \mathrm{~h}$ after ovariectomy. Animals were killed at $28 \mathrm{~h}$ of ovariectomy.

Mammary glands, collected at 24 and $36 \mathrm{~h}$ of ovariectomy, were incubated for $5 \mathrm{~h}$ at $37^{\circ} \mathrm{C}$ with actinomycin D $(1 \mu \mathrm{g} / \mathrm{ml})$, cycloheximide $(0.25-4 \mu \mathrm{g} / \mathrm{m} l)$, or puromycin $(10 \mu \mathrm{g} / \mathrm{ml})$ in the total volume of $1 \mathrm{ml}$. Incubation medium was Medium 199 containing $0.2 \%$ BSA (pH 7.4). Fifty $\mu l$ of the reaction mixture were removed at $3.5 \mathrm{~h}$ of the incubation, and $50 \mu \mathrm{l}$ of fresh medium containing ${ }^{125} \mathrm{I}$-PRL with or without 5 $\mu \mathrm{g}$ of unlabeled PRL were added.

Statistical analysis: The result is expressed as mean $\pm S E$. Statistical analysis of the results was made by Student's two-tailed $t$-test. Differences were considered to be significant at $P<0.05$.

\section{Results}

Changes in PRL binding and serum lactogenic activity after ovariectomy: The timedependent changes in both specific ${ }^{125} \mathrm{I}-\mathrm{PRL}$ binding to the mammary PRL receptor and serum concentration of lactogenic activity were examined in ovariectomized mice (Fig. 1). The amount of specific ${ }^{125} \mathrm{I}$-PRL binding increased slightly during $16 \mathrm{~h}$ after ovariectomy, but increased rapidly thereafter, about 2.7 times at $20 \mathrm{~h}(P<0.05)$ and reached maximum around $32 \mathrm{~h}$. The amount at $32 \mathrm{~h}$ was about 7 times larger than that at $0 \mathrm{~h}$ or of sham-ovariectomized control $(P<0.01)$. Although the ovariectomized mice maintained the high level of lactogenic activity $(140-212 \mathrm{ng} / \mathrm{m} l)$ in serum from 0 to $20 \mathrm{~h}$ of ovariectomy, the concentration decreased to about $18 \mathrm{ng} / \mathrm{ml}$ at $24 \mathrm{~h}$ of ovariectomy $(P<0.01)$. The low level was kept from 24 to $36 \mathrm{~h}$. In the present experiments, abortion occurred around $20 \mathrm{~h}$ after ovariectomy.

Effects of actinomycin D and cycloheximide 


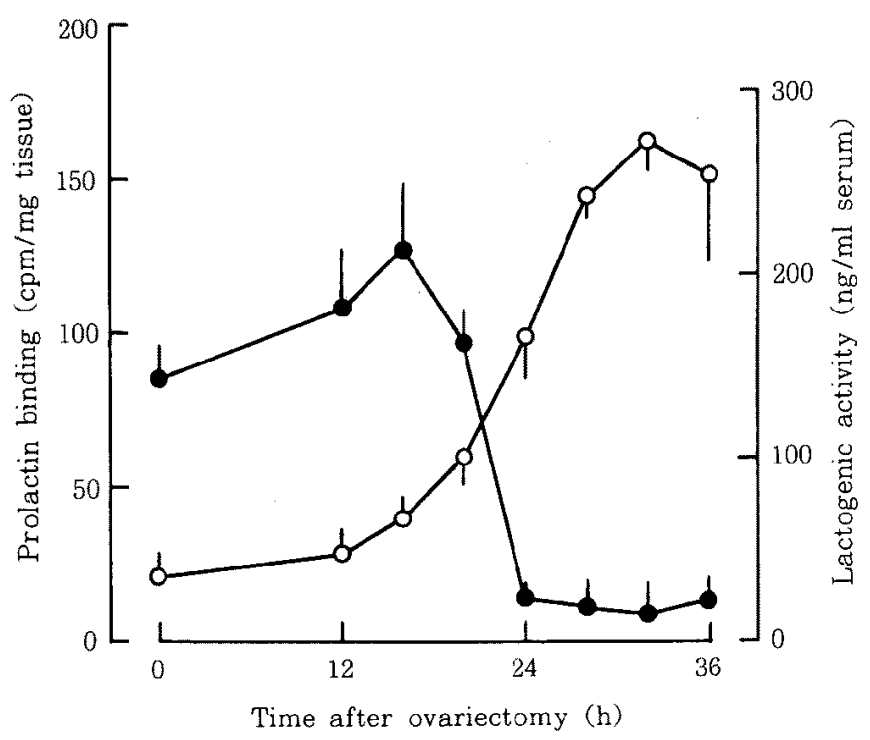

Fig. 1. Time-dependent changes in the PRL binding $(O)$ and serum lactogenic activity $(\mathbf{O})$ after ovariectomy. mean $\pm \mathrm{SE}, \mathrm{n}=5$.

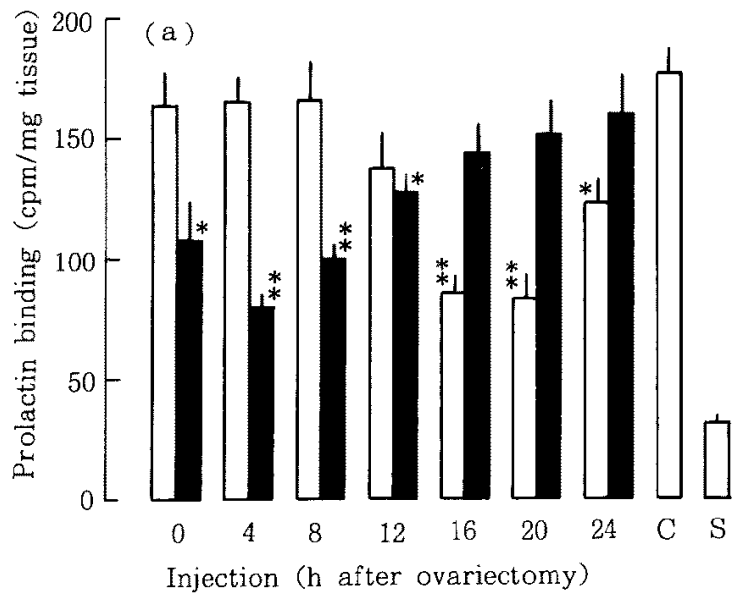

(b)

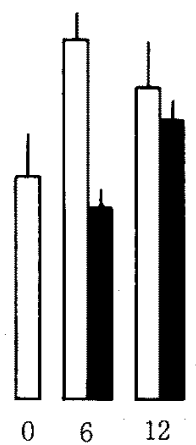

$\mathrm{h}$ after injection

Fig. 2. $a, b$. Effects of actinomycin D and cycloheximide on the change in specific binding of PRL in vivo. (a) : Mice, received the injection of actinomycin $D$ (closed) or cycloheximide (open) at the time after ovariectomy indicated, were used for the PRL binding assay at $28 \mathrm{~h}$ of ovariectomy. $\mathrm{C}$ : control injected with saline at $0 \mathrm{~h}$ of ovariectomy, $S$ : sham-ovariectomized control. mean $\pm S E, n=5$. Data were compared with the ovariectomized and saline-injected control. " ; $P<0.05,{ }_{*}^{*} ; P<0.01$. (b) : Cycloheximide was administered at $24 \mathrm{~h}$ of ovariectomy. Animals were killed at 6 and $12 \mathrm{~h}$ after the injection. Saline-injected (open) and cycloheximide-injected groups (closed). mean $\pm \mathrm{SE}, \mathrm{n}=4$. 


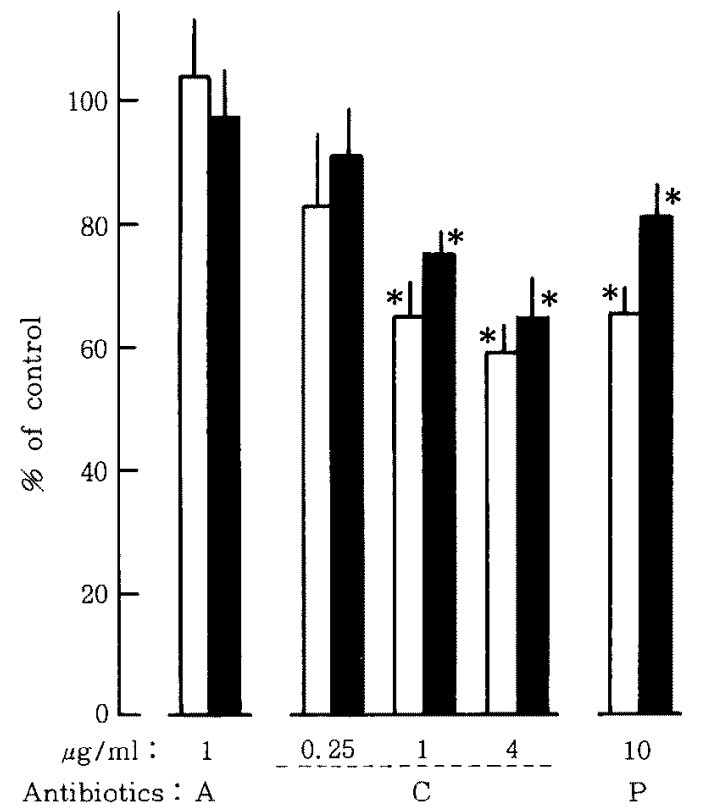

Fig. 3. Effects of actinomycin D, cycloheximide and puromycin on the change in specific binding of PRL in vitro. Mammary tissue slices, collected at 24 (open) or $36 \mathrm{~h}$ (closed) after ovariectomy, were incubated in the presence of actinomycin $\mathrm{D}(\mathrm{A})$, cycloheximide (C) or puromycin (P) for $5 \mathrm{~h}$ at $37^{\circ} \mathrm{C}$. meant $\mathrm{SE}, \mathrm{n}=5$. Data were compared with that obtained in the absence of inhibitor. ${ }^{*} ; P<$ 0.05 .

on PRL binding in vivo: Actinomycin $\mathrm{D}$ and cycloheximide were injected at different time after ovariectomy, and all mice were killed at $28 \mathrm{~h}$ of the operation. During $28 \mathrm{~h}$, the amount of specific ${ }^{125} \mathrm{I}-\mathrm{PRL}$ binding increased 6 times, compared with that at $0 \mathrm{~h}$ or of sham-ovariectomized control. As shown in Fig. 2a, actinomycin $\mathrm{D}$ and cycloheximide inhibited the increase in specific binding of ${ }^{125} \mathrm{I}-\mathrm{PRL}$ in a different time-dependency. Actinomycin D was effective only when that was injected between 0 and $12 \mathrm{~h}$ of ovariectomy. By the injection at $4 \mathrm{~h}$ of ovariectomy, the amount of specific ${ }^{125} \mathrm{I}-\mathrm{PRL}$ binding decreased to about half of that of the saline-injected control. The effect of cycloheximide became effective by the injection after $16 \mathrm{~h}$ of ovariectomy. Regardless either actinomycin D or cycloheximide was injected and also regardless of the time of injection, the serum concentration of lactogenic activity did not differ from the saline-injected control and ranged in the low level from 15.5 to $19.0 \mathrm{ng} / \mathrm{ml}$ (data not shown). Fig. $2 \mathrm{~b}$ showed that cycloheximide inhibited the increase in PRL binding until $6 \mathrm{~h}$ after the injection. The amount of ${ }^{125} \mathrm{I}-\mathrm{PRL}$, however, slightly increased by $12 \mathrm{~h}$ after injection. This suggests that cycloheximide is effective for less than $12 \mathrm{~h}$ after the injection in vivo.

Effects of actinomycin D, cycloheximide and 


\section{Effect of Inhibitors on Mammary Prolactin Receptor}

puromycin on PRL binding in vitro: The effect of inhibitors on PRL binding was examined in the in vitro system (Fig. 3). Although the addition of actinomycin $D$ did not affect the amount of specific ${ }^{125}$ I-PRL binding to the mammary tissue slices, both cycloheximide and puromycin decreased it significantly. Cycloheximide inhibited the binding in a dose dependent manner. At $4 \mu \mathrm{g} / \mathrm{m} l$, it decreased the amount of specific binding to $59 \%$ as compared with in the absence of inhibitor. The in vitro experiment also revealed that the mammary glands taken at $24 \mathrm{~h}$ after ovariectomy were more sensitive to cycloheximide and puromycin than those at $36 \mathrm{~h}$.

\section{Discussion}

We have reported that the level of lactogenic activity in serum of mice at mid-pregnancy is very high ${ }^{12)}$, and the fact was confirmed in this study. The author showed here that this activity fell sharply between 20 and $24 \mathrm{~h}$ after ovariectomy, accompanied by the occurrence of abortion. As the serum concentration of PRL was kept unchanged between 0 and $24 \mathrm{~h}$ of ovariectomy ${ }^{3)}$, it is apparent that the placental lactogen disappears from the circulation after $20 \mathrm{~h}$ of ovariectomy. Therefore, it was possible to ascribe the increase in the binding of PRL to the mammary receptor to that the receptor became free of the masking effect of placental lactogen and then was able to bind with PRL. However, although the serum lactogenic activity had decreased to the basal level also in inhibitors-treated mice, both actinomycin $\mathrm{D}$ and cycloheximide inhibited the increase in PRL binding in vivo. In addition, cycloheximide and puromycin directly acted on the mammary gland and inhibited the increase in PRL binding in the in vitro experiment. The binding of PRL to the rat liver PRL receptor was the highest during pregnancy in spite of the high level of serum lactogenic activity ${ }^{4}$. These evidence suggested that the increase in the PRL binding caused by ovariectomy is ascribed to the newly synthesis of the receptor triggered by ovariectomy, rather than to the disappearance of the effect of placental hormones. The PRL binding increases in the presence of glucocorticoid hormones in vivo ${ }^{31}$ and in vitro ${ }^{11)}$. Until now, it is not known when synthesis of the PRL receptor is initiated by ovariectomy.

The effective period of an inhibitor of translation, cycloheximide, was later than that of an inhibitor of transcription, actinomycin D. The action of cycloheximide became apparent $16 \mathrm{~h}$ after ovariectomy, while the action of actinomycin D could be observed only when the inhibitor was given shortly after ovariectomy. This indicated that the initiation of mRNA synthesis for the receptor increase was induced shortly after ovariectomy. However, the inhibitory action of actinomycin $\mathrm{D}$ could no longer be observed after $16 \mathrm{~h}$ of ovariectomy. I speculated that the messenger RNA for the receptor synthesis had already been accumulated in the mammary gland by this time. This speculation would be supported by OHsAKo et al. who reported in the midpregnant rat that the rate of uridine incorporation into the mammary gland was very high between 0 and $16 \mathrm{~h}$ after ovariectomy ${ }^{8}$, and that the lactose synthesis was suppressed by progesterone only when the hormone was administered within $4 \mathrm{~h}$ after ovariectomy ${ }^{9}$.

In the present experiments, the time-dependent effect of an inhibitor of transcription or of translation on the binding of PRL to the mammary gland was clear in the ovariectomized mid-pregnant mouse. It was concluded that the increase in PRL binding caused by ovariectomy was mediated by the initiation of the receptor synthesis. It was suggested that transcription for the receptor synthesis occurred shortly after ovariectomy.

\section{Acknowledgement}

This work was supported in part by grants from the Ministry of Education, Science and 
Culture of Japan (2556037) and from Daiichi Pharmaceutical Co., Tokyo.

\section{References}

1) Hartgaya, 'T., S. Sakai and K. Kohmoto, Induction of mammary prolactin receptors and lactose synthesis after ovariectomy in the pregnant mouse. Endocrinol. Japon., 25: 157-161. 1978.

2) Harigaya, T., K. Коhmoto, K. Ôta and A. Yokoyama, Specific binding of prolactin to the mammary gland and lactose synthesis in pregnant rats after removal of ovaries or ovaries and adrenals. Endocrinol. Japon., $27:$ 39-41. 1980.

3) Harigaya, T., S. Sakai, K. Kohmoto and Y. SHodA, Influence of glucocorticoids on mammary prolactin receptors in pregnant mice after ovariectomy. J. Endocr., 94: 149-155. 1982

4) Hayden, T.J., R.C. Bonney and I.A. Forsyth, Ontogeny and control of prolactin receptors in the mammary gland and liver of virgin, pregnant and lactating rats. J. Endocr., 80 : 259-269. 1976.

5) HolComb, H.H., M.E. CostLow, R.A. Buschow and W.L. MCGuire, Prolactin binding in rat mammary gland during pregnancy and lactation. Biochim. Biophys. Acta, 428 : 104-112. 1976.

6) Kelly, P.A., T. Tsushima, R.P.C. ShiU and H.G. Friesen, Lactogenic and growth hormone-like activities in pregnancy determined by radioreceptor assays. Endocrinology, $99: 765-774.1976$.

7) OHSAKo, K., K. Ôta and A. Yokoyama, Nucleic acid syntheses in the mammary gland during lactogenesis caused by ovariectomy in the mid-pregnant rat. Japan. J. Anim. Reprod., 32 : 7-12. 1986.

8) OHSAKO, K., K. ÔTA, and A. YoKOYAMA, Chronological changes in hormone levels and suppressing effect of progesterone after ovariectomy in the mid pregnant rats. Flemish Vet. J., 55 : 266-273. 1986.

9) SAKAI, S. and K. Koнmoto, Binding of mouse choriomammotropin to prolactin receptors in the mouse mammary gland. Endocrinol. Japon., 23 : 499-503. 1976.

10) SakaI, S., K. Конмото and T. Johke, A receptor site for prolactin in lactating mouse mammary tissues. Endocrinol. Japon., 22 : 379-387. 1975.

11) Sakai, S., P. Bowman, J. Yang, K. MCCORMICK and S. NANDI, Glucocorticoid regulation of prolactin receptors on mammary cells in culture. Endocrinology, 104 : 1447-1449. 1979.

12) SAKAI, S., K. Конмото and Y. ShodA, Specific ${ }^{125} \mathrm{I}$-prolactin binding in the mouse mammary gland during pregnancy and lactation. Jpn. J. Zootech. Sci., 52: 798804. 1981.

13) Shru, R.P.C., P.A. Kelly and H.G. FrIESEN, Radioreceptor assay for prolactin and other lactogenic hormones. Science, 180 : 968-971. 1973. 
Effect of Inhibitors on Mammary Prolactin Receptor

\title{
妊娠中期卵巣除去マウス乳腺におけるプロラクチンレセ プターへのプロラクチンの結合に及ぼすアクチノ マイシン D と蛋白質合成阻害骭の影響
}

\author{
酒井仙吉
}

東京大学農学部，東京都文京区 113

\begin{abstract}
卵巣除去した妊娠中期のマウスでは，卵巣除去後 16 時間加ら乳腺へのプロラクチン結合量の増加が

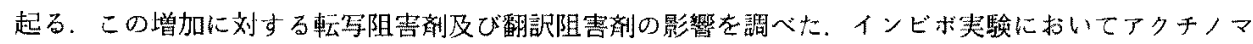
イシン D 及びサイクロヘキシミドの有効な効果がみられたが, 卵巣除去後の時問は両者で異なった。 アクチノマイシン D は，卵紧除去直後から 12 時間までに投与すると增加を抑制した。一方，サイク ロへキシミドは，除去後 16 時間以降に投与すると增加を抑制した，次に畉紧除去後 24 時問及び 36 時 間経過したマウスから得た乳腺組織をアクチノマイシン D, サイクロヘキシミド，あるいはピューロ マイシンの存在下でインビトロで培養し，そのプロラクチン結合量に対する影響を調べた．アクチノマ イシン D の添加はプロラクチン結合に影響を与えなかったが，サイクロへキシミドおよびピューロマ イシンは共に有意に結合を抑制した。 これらの結果蛙，畉巣除去によって新しくプロラクチンレセプタ 一が作られること，卵巣除去後早い時期から乳腺細胞でプロラクチンレセプタ一が作られるための転写 が始まること，走した。
\end{abstract}

日畜会報，63(1): 1-7, 1992 